\title{
Changes of the Casein Complex in Sterilized Concentrated Skim Milk during Storage
}

\author{
Takayoshi Aoki and Tsuneaki IMAMURA \\ Department of Food Chemistry and Technology, Faculty of Fisheries and Animal Husbandry, \\ Hiroshima University, Fukuyama, Hiroshima 720
}

Received August 3, 1973

\begin{abstract}
Visible and chemical changes of sterilized concentrated skim milk prepared laboratorially were studied over a long period of storage, and on the basis of the results the changes of the calcium-caseinate-phosphate complex were discussed.

The results obtained are summarized as follows. (1) The formation of visible sediment and "whey off" were observed on the 50th day of storage. The increment of the viscosity was not so large during storage. (2) The remarkable increase of the soluble casein was observed, and its proportion to total casein amounted to about $2 / 3$ on the 120 th day of storage. Only small amount of calcium bound to the soluble casein. (3) Each amount of calcium and inorganic phosphorus in the ultracentrifugal whey decreased gradually, and that of magnesium increased during storage. (4) The ratios of $\mathrm{Ca} / \mathrm{N}$ and $\mathrm{P} / \mathrm{N}$ in the casein complex increased extremely after storage.
\end{abstract}

Sterilized concentrated milk (SCM) seems to have bright future due to its considerably high keeping quality and palatable flavor. However, the formation of sediment or gelation caused by protein denaturation during storage remains as a problem to be resolved. Tarassuk et al. ${ }^{11}$ investigated various conditions for the manufacture of SCM and indicated some directions toward its practical use. Leviton et al. ${ }^{2,3)}$ examined the effects of calcium salts, pyrophosphate, and manganese on the gelation in SCM during storage. Wilson et al. ${ }^{4}$ ) studied on the aggregation of casein particles by an ultracentrifugal method. Other workers ${ }^{5 \sim 7}$ ) observed the formation of the network among casein particles by use of an electron-microscope.

The destabilization of the casein complex* in the SCM is important for the discussion in this research. Nakai et al. ${ }^{8}{ }^{1}$ studied on the changes of the casein in the SCM during storage. However, the literatures concerned with its mechanisms are rarely found. In our present study a laboratorially sterilized concentrated skim milk (SCSM) was prepared

* This term was used in this report to represent the calcium-caseinate-phosphate complex in milk. and the changes during storage were examined.

\section{MATERIALS AND METHODS}

Preparation of the SCSM. Material milk used in these experiments was raw herd milk of about 60 cows. Skim milk was prepared from the material milk by centrifugation without warming and concentrated up to $1 / 2.5$ of the original volume with a rotary evaporator under $40^{\circ} \mathrm{C}$ for about $1 \mathrm{hr}$. A portion of the concentrated skim milk was injected into many glass tubes which had $4 \mathrm{~mm}$ of diameter, $1 \mathrm{~mm}$ of thickness, and about $30 \mathrm{~cm}$ of length. Then, their ends were sealed by heating. Every glass tube containing the sample was heated by immersing in the oil bath at $135^{\circ} \mathrm{C}$ for $45 \mathrm{sec}$, followed by cooling in cold water.

The temperatures of the samples in the glass tubes were determined with a $\mathrm{CA}$ (chromel-alumel) thermocouple which had $1.6 \mathrm{~mm}$ of diameter and recorded with an autorecorder every $10 \mathrm{sec}$. As shown in Fig. 1, when the oil bath was held at $80^{\circ} \mathrm{C}$ or $100^{\circ} \mathrm{C}$, the temperature of the sample in each glass tube which was immersed for $45 \mathrm{sec}$ became to 75.5 and $96.0^{\circ} \mathrm{C}$, respectively. The differences between the inner samples and outer oil were 4.5 and $4.0^{\circ} \mathrm{C}$, respectively. Based on the assumption that such a difference might have occurred by heating at $135^{\circ} \mathrm{C}$ for $45 \mathrm{sec}$, the temperature of the inner sample was estimated to become above $130^{\circ} \mathrm{C}$. After the heat-treatment, the samples were allowed to stand for a long period at $30^{\circ} \mathrm{C}$ and examined every 10 days. 


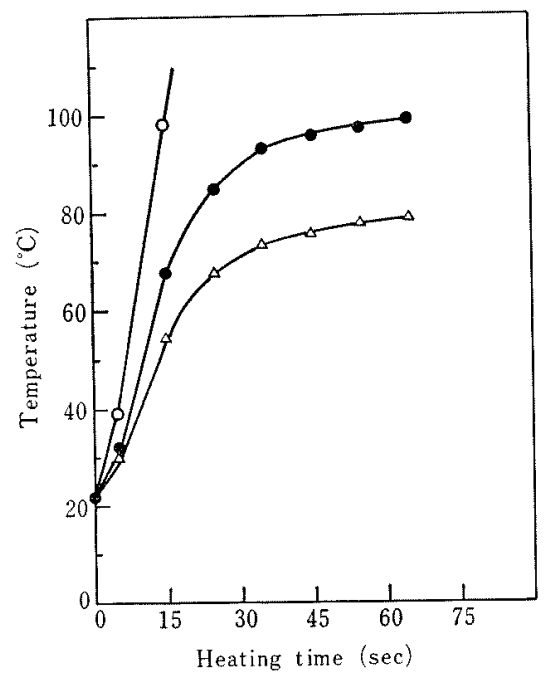

FIG. 1. Temperature of the Inner Milk in the Glass Tube Heated in the Oil Bath.

The oil bath was stirred with a stirrer.

Temperature of the oil bath: $\triangle-\triangle, 80^{\circ} \mathrm{C}$; $100^{\circ} \mathrm{C} ; \mathrm{O}-\mathrm{O}, 135^{\circ} \mathrm{C}$.

Determination of the relative viscosity. The relative viscosity was measured at $30^{\circ} \mathrm{C}$ with an Ostwald viscometer which took $5.3 \mathrm{sec}$ of water flow time.

Determination of the $\mathrm{pH}$. The $\mathrm{pH}$ was determined with a Hitachi-Horiba $\mathrm{pH}$ meter (Type M-5) using a complex electrode $(\sharp 6208-10 \mathrm{~T})$ at room temperature $\left(20 \sim 25^{\circ} \mathrm{C}\right)$.

Determination of the $N$-distribution in the ultracentrifugal whey. Samples which had been cooled previously at $5^{\circ} \mathrm{C}$ for $4 \mathrm{hr}$ were ultracentrifuged without diluting at $45,000 \mathrm{rpm}(109,800 \times g)$ for $1 \mathrm{hr}$ at $5^{\circ} \mathrm{C}$ with a Hitachi 55-P type 2 ultracentrifuge. The supernatant was termed ultracentrifugal whey in this report. To $1 \mathrm{ml}$ of the ultracentrifugal whey, $3 \mathrm{ml}$ of $1 / 10 \mathrm{M}$ acetate buffer ( $\mathrm{pH} 4.4$ ) was added and stood for $15 \mathrm{~min}$ at $35^{\circ} \mathrm{C}$, followed by filtering through a filter paper. 9 ! Nitrogen in the filtrate was determined by the Kjeldahl method and described as the noncasein-nitrogen (NCN). Nitrogen in $12 \%$ trichloracetic acid (TCA)-soluble fraction from the ultracentrifugal whey was regarded as the nonprotein-nitrogen (NPN). The casein- $\mathrm{N}$ was calculated by the difference between total-N and NCN.

Determination of the nonsedimentation- $N$ by low speed centrifugation. One milliliter of the SCSM and $1.5 \mathrm{ml}$ of water were mixed in a small centrifugal tube for 1 min with a mixer and centrifuged at $500 \times g$ for 15 min. Upper $2 / 3$ part of the content was separated and nitrogen in it was described as the nonsedimentation- $\mathrm{N}$ by low speed centrifugation.
Determination of $\mathrm{Ca}, \mathrm{Mg}$, and $\mathrm{P}$ in the ultracentrifugal whey. Ultracentrifugal whey was digested with perchloric acid. Calcium and magnesium in the solution containing the digest, $500 \mathrm{ppm}$ of strontium and $20 \%$ ethyl alcohol were determined with a Hitachi 207 atomic absorption spectrophotometer.10,11) Determination of phosphorus was carried out by Allen's method. Phosphorus in the digest and that in $12 \%$ TCA-soluble fraction were regarded as the total phosphorus and the inorganic phosphorus, respectively.

Disc-gel electrophoresis. Disc-gel electrophoresis was performed with acrylamide-gel containing $4 \mathrm{M}$ urea according to the method of Groves et al. ${ }^{12}$ For each run $200 \mu \mathrm{g}$ of the casein sample was employed. Electrophoresis at $4 \mathrm{~mA}$ per gel column was performed at $5^{\circ} \mathrm{C}$ for about $1 \mathrm{hr}$. Gels were stained with $0.5 \%$ amido-black solution dissolved in $7 \%$ acetic acid and then destained by means of repeated washing with $7 \%$ acetic acid solution.

Preparation of the casein samples for the disc-gel electrophoresis. Soluble casein was precipitated from the ultracentrifugal whey at $\mathrm{pH} 4.6$, dissolved with caution so as not to exceed over $\mathrm{pH} 7$, and then purified by reprecipitation at $\mathrm{pH} 4.6$ and successive washing with distilled water, ethyl alcohol, and acetone.

Ultracentrifuged casein was washed by a combination of repeated dispersion in distilled water and ultracentri-

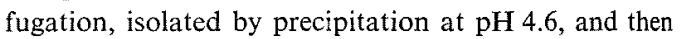
purified in the same manner as in the soluble casein.

Ultrafiltration. Ultrafiltration of the ultracentrifugal whey was performed through a collodion bag (Sartrius membrane filter) at $5^{\circ} \mathrm{C}$ under about $30 \mathrm{mmHg}$.

\section{RESULTS}

\section{Stability of the casein complex during storage of the SCSM}

As shown in Table I, the relative viscosity increased at early stage of storage, but its increment was not so large during storage. On the 50th day of storage, the formation of visible sediment and "whey off" were observed. No changes of the pH occurred. The amount of sedimentation- $\mathrm{N}$ by low speed centrifugation continued to increase till the 60th day of storage and decreased thereafter. Since most of casein molecules exist as the state of a casein complex in milk, the amount of nitrogen sedimented by ultracentrifugation and not by low speed centrifugation is able to be 
Table I. Changes of the Relative Viscosity AND THE $\mathrm{pH}$ OF THE SCSM DURING STORAGE

\begin{tabular}{ccc}
\hline $\begin{array}{c}\text { Storage time } \\
\text { (days) }\end{array}$ & $\begin{array}{c}\text { Relative } \\
\text { viscosity }\end{array}$ & $\mathrm{pH}$ \\
\hline $\begin{array}{c}\text { Before } \\
\text { sterilization }\end{array}$ & 2.23 & 6.42 \\
\hline $0^{a !}$ & 3.15 & 6.39 \\
10 & 2.60 & - \\
20 & 2.83 & - \\
30 & 5.72 & 6.39 \\
40 & 4.64 & - \\
50 & Whey off & - \\
120 & - & 6.38 \\
\hline
\end{tabular}

a) Immediately after sterilization.

regarded as an index of the stable casein complex. Its changes were shown in Fig. 2. The stable casein complex became negligible in amount after the 60th day of storage.

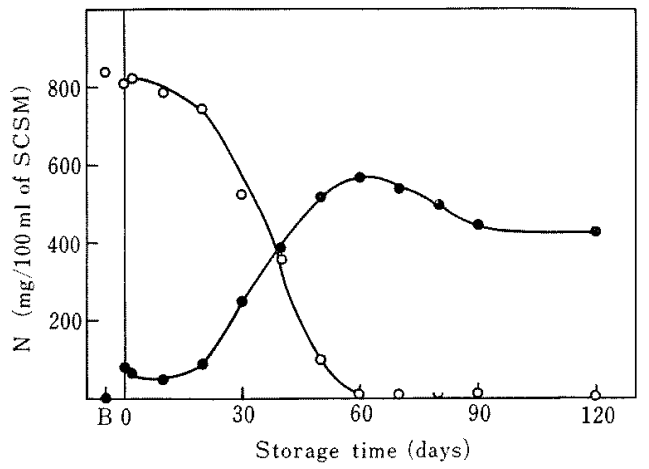

Fig. 2. Changes of the Amounts of Sedimentation-N by Low Speed Centrifugation and $\mathrm{N}$ Sedimented by Ultracentrifugation but Not by Low Speed Centrifugation during Storage of the SCSM.

$B$, before sterilization; 0 , immediately after sterilization.

- - sedimentation- $\mathrm{N}$ by low speed centrifugation; $\mathrm{O}-\mathrm{O}, \mathrm{N}$ sedimented by ultracentrifugation but not by low speed centrifugation.

Changes of caseins in the ultracentrifugal whey

As shown in Fig. 3, the amount of total-N in the ultracentrifugal whey somewhat fell by the heat-treatment for the sterilization and continued to increase during subsequent storage. The increase was rapid from the 20 th day till about the 50th day, and on the 30th day the amount of total- $\mathrm{N}$ went up to the level

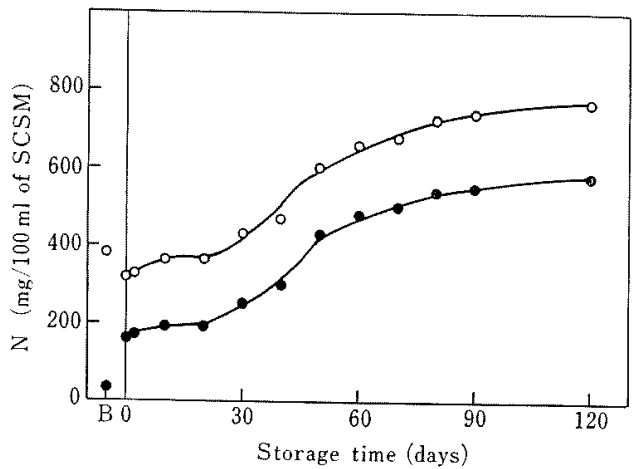

FIG. 3. Changes of the Amounts of Total-N and Casein- $N$ in the Ultracentrifugal Whey during Storage of the SCSM.

B, before sterilization; 0 , immediately after sterilization.

$\mathrm{O}-\mathrm{O}$, total-N; casein-N.

before sterilization. On the basis of the fact that the increasing tendency was similar to that of casein- $\mathrm{N}$, the increment of total- $\mathrm{N}$ is considered to be mainly caused by that of casein-N. In this report, casein- $\mathrm{N}$ in the ultracentrifugal whey was regarded as soluble casein- $\mathrm{N}$, and the proportions of soluble casein- $\mathrm{N}$ to total casein- $\mathrm{N}$ in the SCSM were $3.4 \%$ before sterilization, $18 \%$ immediately after sterilization, and $68 \%$ on the 120th day of storage, respectively. However, it is noteworthy that the net value of soluble casein- $\mathrm{N}$ after sterilization must be lower than the above one because a part of nitrogen of heatdenatured whey proteins is involved.

The increase of soluble casein- $N$ was kept after the 60th day of storage. Accordingly, the decrease of sedimentation- $\mathrm{N}$ by low speed centrifugation is due to the increase of the soluble casein.

Figure 4 shows the patterns of the disc-gel electrophoresis on the different casein samples, and those assigned by No. $1 \sim 4$ are of the soluble casein and No. $5 \sim 8$ are of the ultracentrifuged casein. Judging from the patterns of the soluble casein, the zone of $\beta$ casein was larger than that of $\alpha_{s}$-casein before sterilization, and the zone of $\alpha_{s}$-casein became larger during storage and had similar width to that of $\beta$-casein after the 60th day of stor- 


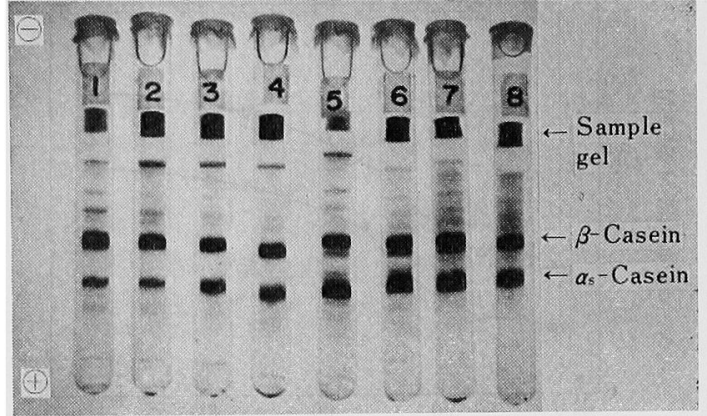

FIG. 4. Patterns of the Disc-gel Electrophoresis of the Casein Samples.

The gels contained $4 \mathrm{M}$ urea. Electrophoresis at $4 \mathrm{~mA}$ per column was performed at $5^{\circ} \mathrm{C}$.

(1) soluble casein before sterilization; (2) soluble casein immediately after sterilization; (3) soluble casein on the 60th day of storage; (4) soluble casein on the 120th day of storage; (5) ultracentrifuged (UC) casein before sterilization; (6) UC casein immediately after sterilization; (7) UC casein on the 60th day of storage; (8) UC casein on the 120 th day of storage.

age. Consequently, the increment of soluble casein- $\mathrm{N}$ seems to be composed of not only $\beta$-casein but also $\alpha_{s}$-casein.

On the patterns of the ultracentrifuged casein, the zones of $\alpha_{s}$-casein and $\beta$-casein became somewhat unclear and the position between origin and $\beta$-casein was stained deep after the 60th day of storage. Changes of the bands with mobility between origin and $\beta$ casein seem to be slight during storage. These bands seem to be of TS- and R-casein.

The increment of NCN or NPN in the ultracentrifugal whey, in contrast to that of soluble casein-N, was very small as shown in Fig. 5. For example, the proportion of NPN to total-N in the SCSM, which was $7.2 \%$ immediately after sterilization, was still only $8.2 \%$ on the 120 th day of storage.

Changes of $\mathrm{Ca}$-, $\mathrm{Mg}$-, and P-contents in the ultracentrifugal whey

Both the amounts of calcium and magnesium in the ultracentrifugal whey decreased by the heat-treatment for the sterilization, but the amount of calcium decreased and that of magnesium increased during storage.

As shown in Fig. 3, 2/3 of total casein was occupied by the soluble casein when the

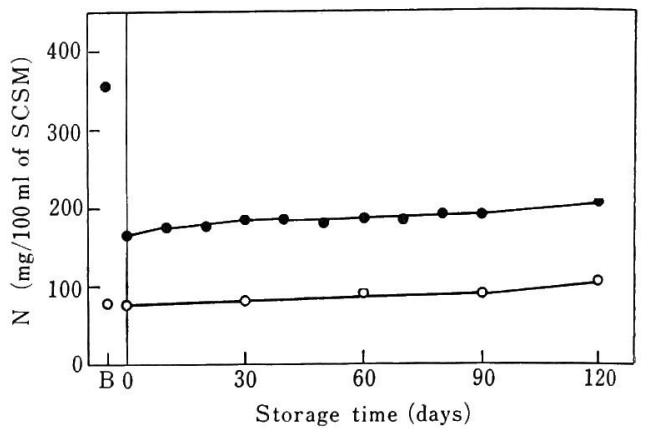

FIG. 5. Changes of the Amounts of NCN and NPN in the Ultracentrifugal Whey during Storage of the SCSM.

$\mathrm{B}$, before sterilization; 0 , immediately after sterilization.

- - NCN; O-O, NPN.

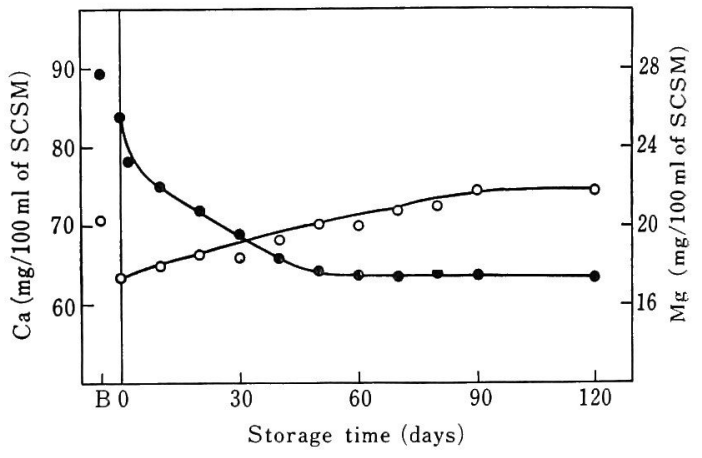

Fig. 6. Changes of the Amounts of $\mathrm{Ca}$ and $\mathrm{Mg}$ in the Ultracentrifugal Whey during Storage of the SCSM.

$\mathrm{B}$, before sterilization; 0 , immediately after sterilization.

- - $\mathrm{Ca} ; \mathrm{O}-\mathrm{O}, \mathrm{Mg}$.

storage time reached to 120 days. Accordingly, the determination of each amount of bound type calcium and magnesium in the soluble casein fraction seems to be available for the discussion on this investigation. The two bound type elements were isolated by means of ultrafiltration. Table II shows the amounts of calcium, magnesium, and phosphorus in the ultracentrifugal whey and those in the ultrafiltrate. Each amount of bound type calcium and magnesium in $100 \mathrm{ml}$ of the ultracentrifugal whey was $3.9 \mathrm{mg}$ and $0.9 \mathrm{mg}$, respectively, on the 120th day of storage.

As shown in Fig. 7, both total and inorganic 
Table II. The Amounts of $\mathrm{Ca}, \mathrm{Mg}$, And

P IN the Ultracentrifugal Whey and Ultrafiltrate Which Were Fractionated FROM THE SCSM STORED FOR 120 DAYS

\begin{tabular}{lcccc}
\hline & $\mathrm{Ca}$ & $\mathrm{Mg}$ & Total-P & $\mathrm{Pi}^{a i}$ \\
\hline $\begin{array}{l}\text { Ultracentrifugal } \\
\text { whey }\end{array}$ & 63.4 & 21.4 & 94.0 & 65.0 \\
Ultrafiltrate & 59.5 & 20.5 & 77.3 & 63.9 \\
\hline
\end{tabular}

Numbers in table indicate $\mathrm{mg} / 100 \mathrm{ml}$.

a) Inorganic phosphorus.

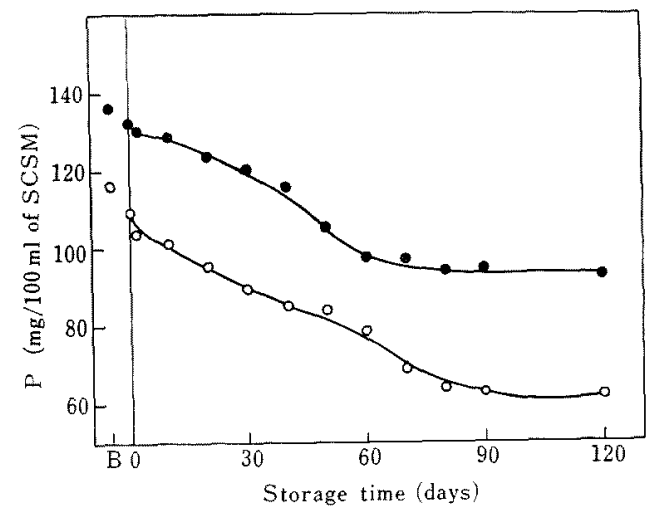

FIG. 7. Changes of the Amounts of Total-P and Pi in the Ultracentrifugal Whey during Storage of the SCSM.

$\mathrm{B}$, before sterilization; 0 , immediately after sterilization; Pi, inorganic phosphorus.

$\longrightarrow$, total-P; $\mathrm{O}-\mathrm{O}, \mathrm{Pi}$.

phosphorus in the ultracentrifugal whey decreased by the heat-treatment for the sterilization and continued to decrease with prolonged storage.

\section{Changes of the ratios of $C a / N$ and $P / N$ in the casein complex}

The ratios of $\mathrm{Ca} / \mathrm{N}, \mathrm{P} / \mathrm{N}$, and $\mathrm{Ca} / \mathrm{P}$ in the casein complex were calculated from the analytical data of the ultracentrifugal whey without correcting the volume which was occupied by the ultracentrifuged casein complex. As shown in Table III, both the ratios of $\mathrm{Ca} / \mathrm{N}$ and $\mathrm{P} / \mathrm{N}$ showed only small changes by the heat-treatment for the sterilization and increased extremely during storage. The ratio of $\mathrm{Ca} / \mathrm{P}$ showed a little decrease during storage.
Table III. Changes of the Ratios among the Ca-, P-. AND N-CONTENTS IN THE ULTRACENTRIfuged Casein Complex of THe SCSM DURING STORAGE

\begin{tabular}{ccccc}
\hline $\begin{array}{c}\text { Storage } \\
\text { time } \\
\text { (days) }\end{array}$ & $\mathrm{Ca} / \mathrm{N}$ & $\mathrm{P} / \mathrm{N}$ & $\mathrm{Pi} / \mathrm{N}$ & $\mathrm{Ca} / \mathrm{P}$ \\
\hline $\begin{array}{c}\text { Before } \\
\text { steriliza- } \\
\text { tion }\end{array}$ & 0.246 & 0.120 & 0.064 & 2.05 \\
\hline $0^{a 1}$ & 0.234 & 0.116 & 0.067 & 2.02 \\
30 & 0.289 & 0.150 & 0.090 & 1.92 \\
60 & 0.422 & 0.256 & 0.186 & 1.64 \\
90 & 0.492 & 0.307 & 0.231 & 1.60 \\
120 & 0.544 & 0.338 & 0.268 & 1.61 \\
\hline
\end{tabular}

a) Immediately after sterilization.

Pi: Inorganic phosphorus.

\section{DISCUSSION}

According to Ellertson et al., ${ }^{13)}$ the SCM which was flash-sterilized above $130^{\circ} \mathrm{C}$ increased remarkably in its viscosity and gelled during storage at room temperature. On the SCSM which was laboratorially prepared for this experiment, the formation of sediment and "whey off" were observed, but the remarkable increase of the viscosity did not occur during storage at $30^{\circ} \mathrm{C}$. The SCSM which was prepared in the similar conditions to this experiment increased remarkably in its viscosity and gelled when it was stored at $5^{\circ} \mathrm{C}^{14)}$ The formation of sediment in the SCSM is not caused by the acid-coagulation of casein because the $\mathrm{pH}$ of the SCSM did not decrease during storage, as shown in Table I. Another cause of the casein-coagulation is the effect of the colloidal calcium phosphate which affects the heat-coagulation of milk as mentioned by McGann et al. ${ }^{15}$ Yamauchi et al. ${ }^{16,17)}$ reported the facts that ultrafiltrable calcium and inorganic phosphorus decreased and that the ratios of $\mathrm{Ca} / \mathrm{N}$ and $\mathrm{P} / \mathrm{N}$ of the destabilized casein complex increased during frozen storage of milk. Consequently, the remarkable increase of the ratios of $\mathrm{Ca} / \mathrm{N}$ and $\mathrm{P} / \mathrm{N}$ which was observed during storage of the SCSM seems to be one of the causes of the destabilization of the casein 
complex.

According to the report by Fox et al., ${ }^{18)}$ high-heat-treatment of the concentrated milk resulted in the formation of the soluble casein, namely, nonsedimentable casein. A similar result was observed in this experiment. The amount of casein- $\mathrm{N}$ in the ultracentrifugal whey increased by the heat-treatment for the sterilization. However, not all the increment-N is due to the soluble casein because a part of the increment- $\mathrm{N}$ comes from heat-denatured whey proteins which coprecipitate with casein at isoelectric point. Consequently, it is difficult to conclude that the soluble casein increased surely by the heat-treatment. On the other hand, the fact that the soluble casein increased during storage is surely shown in Fig. 3, and it is reasonable, from the results in Fig. 2 and Fig. 3, to consider that the soluble casein was derived from not only stable casein complex but also destabilized one.

It is postulated that casein micelles are composed of numerous, loosely packed, calcium-caseinate-complex units, joined in association by a combination of calcium and colloidal calcium phosphate linkage. ${ }^{19,20)}$ Colloidal calcium phosphate is an essential component for the presence of casein as a large stable particle, namely, casein micelle. The casein in the colloidal phosphate-free milk is not sedimented by ultracentrifugation. However, the soluble casein increased during storage of the SCSM in spite of increase of the colloidal calcium phosphate in the casein complex. As shown in Table II, only small amounts of calcium and inorganic phosphorus bound to the soluble casein. Accordingly, the soluble casein seems to be disaggregated from the casein complex by the fission of the bond which combines directly calcium and casein in milk.

The increment of NCN or NPN in the ultracentrifugal whey was small and only small changes of TS- and R-casein were observed on the patterns of the electrophoresis of the casein samples. On the basis of the latter fact and the report by Kaminogawa et al., ${ }^{21)}$ the effect of a milk protease seems to be slight. Kaminogawa et al. reported that the bands of TS- and R-casein on the electrophoresis became larger when casein was hydrolyzed by a milk protease.

Magnesium showed different changes from that of calcium. According to Pyne, ${ }^{22)}$ magnesium destabilized the casein complex on its heat-coagulation as effectively as calcium, in contrast to its inferior role on the rennetcoagulation. Furthermore, investigations on the effects of magnesium are desired.

\section{REFERENCES}

1) N. P. Tarassuk and A. F. Tamsma, J. Agr. Food. Chem., 4, 1033 (1956).

2) A. Leviton and M. J. Pallansh, J. Dairy Sci., 44, 442 (1961).

3) Idem, ibid., 45, 1045 (1962).

4) H. K. Wilson, E. O. Herreid and R. McL. Whitney, J. Dairy Sci., 43, 165 (1960).

5) D. G. Schmidt and W. Buchheim, Milchwissenschaft, 23, 505 (1968).

6) P. W. Board, J. M. Bain and D. W. Gove, J. Dairy Res., 37, 513 (1970).

7) D. G. Schmidt, Neth. Milk and Dairy J., 22, 40 (1968).

8) S. Nakai, H. K. Wilson and E. O. Herreid, J. Dairy Sci., 47, 754 (1964).

9) T. Tsugo, K. Yamauchi and S. Yoshikawa, Jap. J. Zootech. Sci., 33, 47 (1962).

10) H. Osada and I. Goto, J. Jap. Soc. Food Nut., 20, 349 (1967).

11) D. Mori, I. Goto and H. Osada, ibid., 21, 18 (1968).

12) M. L. Groves and C. A. Kiddy, Arch. Biochem. Biophys., 126, 188 (1968).

13) M. E. Ellertson and S. J. Pearce, J. Dairy Sci., 47, 564 (1964).

14) T. Aoki and T. Imamura, Abstracts of Papers, 47th Meeting of Agr. Chem. Soc. Japan, 1972, p. 234.

15) T. C. A. McGann and G. T. Pyne, J. Dairy Res., 27, 403 (1960).

16) K. Yamauchi, C. -M. Chen and T. Tsugo, Agr. Biol. Chem, 31, 581 (1967).

17) C. -M. Chen and K. Yamauchi, ibid., 33, 1333 (1969).

18) K. K. Fox, M. K. Harper, V. H. Holsinger and M. J. Pallansh, J. Dairy Sci., 50, 443 (1967).

19) C. V. Morr, ibid., 50, 1744 (1967).

20) D. Rose, Dairy Sci. Abstracts, 31, 171 (1969).

21) S. Kaminogawa and K. Yamauchi, Agr. Biol. Chem., 36, 255 (1972).

22) G. T. Pyne, J. Dairy Res., 29, 101 (1962). 